\title{
"Nuestra" América: \\ identidade e juventude nos escritos de Martí e Rodó
}

Regiane Gouveia ${ }^{1}$

\section{Resumo:}

Este artigo analisa como José Martí e José Enrique Rodó apresentaram o conceito de "América" e "juventude" para produzir seus discursos. Investigamos como a América aparece em suas enunciações para identificarmos as razões que levaram ambos os autores a discursarem de maneira a abranger boa parte do continente, não restringindo apenas a seus países e, concomitantemente, marcar uma diferenciação em relação aos Estados Unidos. Também mostra como a modernização no continente, em fins do século XIX e início do XX, contribuiu para a aproximação dos intelectuais neste período.

Palavras-chave: Intelectuais, América, Ideias.

\begin{abstract}
:
This article examines how José Martí and José Enrique Rodó presented the concept of "America" and "youth" to produce their speeches. We investigate how America appears in his enunciations to identify the reasons that led both authors to speak in a way that the speech goes all over the continent and not only their countries. At the same time, they have marked the differences before the United States. It also shows how the modernization on the continent, in the late nineteenth and early twentieth centuries, contributed to bring the intellectuals of this period closer.
\end{abstract}

Keywords: Intellectuals, America, Ideas.

Nas duas últimas décadas do século XIX a América Latina modernizou-se rapidamente ingressando no mercado capitalista mundial. ${ }^{2}$ As potências europeias

\footnotetext{
${ }^{1}$ Mestra em História Social da Cultura pela PUC-Rio. E-mail: regiane_gouveia@yahoo.com.br
}

Revista Eletrônica da ANPHLAC, n. 13, p. 135-136, jul./dez. 2012.

http://revista.anphlac.org.br/index.php/revista 
inauguraram uma nova ordem colonial, ${ }^{3}$ e os Estados Unidos também passaram a fazer parte desse processo, impondo a princípio, sua força no Caribe, na América Central e na Ásia.

Desde a primeira metade do século XIX, os estados nacionais latino-americanos vinham consolidando seu território; no entanto, nas últimas décadas do oitocentos essa questão ainda não estava definida. ${ }^{4}$ Vários conflitos assolavam os países do continente, e guerras civis e revoltas armadas também se fizeram presentes, como a Guerra Grande (1843-1851) no Uruguai, e a rivalidade caudilhista entre federalistas e unitários na Argentina durante as primeiras décadas de emancipação política (GOLDMAN e SALVATORE, 2005). Houve também grandes conflitos externos, em disputas por fronteiras, como a Guerra do Paraguai (1860-1865), envolvendo Brasil, Uruguai e Argentina em uma aliança contra o Paraguai; e a Guerra do Pacífico (1879- 1884), que resultou na perda de parte do território peruano e a saída do mar da Bolívia, em benefício do Chile (PAMPLONA, 2008, p.25).

As novas relações econômicas baseavam-se nas exportações de matérias primas - agropecuárias e minerais - e na importação de manufaturas e máquinas, levando à dependência do capital estrangeiro, a crises e endividamentos. A dinâmica modernizadora gerava várias transformações, mais visíveis no litoral e nas principais áreas produtoras. A euforia, devido ao progresso material evidenciava ainda mais as diferenças entre as áreas urbanas e as rurais.

Neste período, conforme sublinha Susana Rotker, ser moderno significava, em linhas gerais, fazer parte do novo ambiente: estradas de ferro, máquinas a vapor, fábricas, telégrafos, jornais, telefone, descobertas científicas, centros urbanos que

\footnotetext{
${ }^{2}$ Cabe ressaltar que embora várias áreas da América Latina tenham experimentado a modernização, ela não ocorreu de modo simultâneo ou da mesma maneira. Países como a Argentina, Chile, Uruguai e Brasil se destacaram de forma mais positiva no período, comparativamente aos demais.

${ }^{3}$ Ao falarmos em "nova ordem colonial" compartilhamos da definição de Geofrey Barraclough. Para este autor a nova ordem colonial de fins do século XIX e início do XX, diferentemente dos imperialismos que a precederam, esteve relacionada a um movimento de competição por mercados no mundo, no qual as nações mais industrializadas, sobretudo Estados Unidos, Japão e Rússia, se envolveram diretamente (BARRACLOUGH, 1964, p.56).

${ }^{4}$ Após a emancipação política, boa parte das nações recém surgidas precisou conter várias revoltas internas, como por exemplo, o Brasil, que desde a independência enfrentou uma série de revoltas, principalmente durante o período das regências.
}

Revista Eletrônica da ANPHLAC, n. 13, p. 135-163, jul./dez. 2012.

http://revista.anphlac.org.br/index.php/revista 
mudavam a conformação da sociedade e a distribuição das tradicionais classes sociais. De acordo com a autora, a "modernidade", resultante desse processo de transformação, constituía antes de qualquer coisa:

\begin{abstract}
un sistema de nociones: progreso, cosmopolitismo, abundancia y un inagotable deseo por la novedad, derivados de los rápidos adelantos tecnológicos de los que se tenían conocimiento, de los nuevos sistemas de comunicación y, sin duda, de la lógica de consumo propia de las leyes de mercado que se instauraban (ROTKER, 1992, p.32).
\end{abstract}

Não à toa, "modernismo" e "modernidade" foram termos muitas vezes vistos como equivalentes pelos intelectuais latino-americanos que experimentavam essas mudanças (ROTKER, 1992, p.32). Várias regiões do mundo, não apenas a Europa, conforme demonstrou Barraclough, incorporaram as inovações oriundas do progresso técnico e científico, o que propiciou a percepção das mudanças de forma mais generalizada (BARRACLOUGH, 1964, p.49). As inovações tecnológicas, o desenvolvimento científico - tanto na química, medicina, biologia, entre outras áreas - e as propostas de reforma na educação se somaram às novidades.

A imprensa também se modificou, o jornalismo passou a ocupar um lugar privilegiado nesse cenário. Muitos jornais surgiram na América Latina nesse período ou ganharam um espaço maior, como La Prensa (1869) e La Nación (1871) na Argentina que contou com a colaboração de José Martî ${ }^{5}$ e José Enrique Rodó; ${ }^{6}$ El Pregonero (1893) na Venezuela; El Diario de El Salvador (1895); La Prensa (1902) de Lima, e El Tiempo (1911) de Bogotá. A escrita jornalística também se tornaria, segundo Rotker (1992, p.9), uma das primeiras produções genuinamente latino-americanas.

\footnotetext{
5 José Julián Martí y Pérez nasceu em Havana em 1853. Muito jovem se envolveu nas lutas pela independência cubana e em função disso, sofreu desterro na Espanha. Viveu no México, Guatemala, Venezuela e um longo período nos Estados Unidos. Ajudou na organização do Partido Revolucionário Cubano, foi presidente da Sociedade Literária Hispano-Americana e Cônsul do Uruguai, da Argentina e do Paraguai em Nova York. Contribuiu para vários jornais na América Latina e nos Estados Unidos. Lutou na guerra de independência cubana, onde morreu em combate em 1895 (KRAUSE, 2011).

${ }^{6}$ José Enrique Rodó nasceu em Montevidéu em 1871, foi jornalista e professor de literatura. Contribuiu para vários jornais. Participou da vida política do Uruguai sendo eleito deputado por três mandatos. Publicou alguns livros, o mais famoso é Ariel, publicado em 1900, que procurava recuperar a identidade cultural da América Latina através da valorização da cultura ibérica. Essa obra influenciou significativamente a intelectualidade hispano-americana (KRAUSE, 2011).
}

Revista Eletrônica da ANPHLAC, n. 13, p. 135-163, jul./dez. 2012.

http://revista.anphlac.org.br/index.php/revista 
As transformações pelas quais a América Latina passava acabaram criando, de acordo com Susana Zanetti, um ambiente que favoreceu a "religação"7 entre os intelectuais finisseculares. A modernização, de certa forma, propiciou a constituição e o fortalecimento de uma rede intelectual que nortearia o pensamento latino-americano. Ter em conta os vários espaços que contribuíram para o que a autora denomina de "religação" pode nos auxiliar, de uma maneira mais ampla, na compreensão do ambiente comum compartilhado tanto por Martí quanto por Rodó nesse período. Dessa forma, o modernismo literário ${ }^{8}$ também é significativo para compreendermos o cenário em que os dois autores estão inseridos, uma vez que Martí e Rodó estiveram associados a tal movimento. Para Zanetti (1994, p.492), o fato de alguns dos seus expoentes terem permanecido por muito tempo fora de seus países contribuiu para que nos diferentes lugares em que chegavam exercessem uma intensa e sustentada interação pessoal com outros americanos. Essa particular característica dos modernistas estimulou respostas criativas e renovadoras incentivando o espírito de confraria que marcou o movimento. Tal atitude colaborou também para a consolidação de um numeroso grupo de intelectuais de cunho original no qual prevaleceriam os sentimentos de pertencimento e de perspectivas comuns latino-americanas (ZANETTI, 1994, p.492).

Com efeito, estas ideias de unidade se fortaleceram à medida que os Estados Unidos começaram a representar uma ameaça ao continente, ${ }^{9}$ revelando um seu projeto

\footnotetext{
${ }^{7}$ Ao falar em "religação" Suzana Zanetti se refere a uma aproximação no âmbito continental da intelectualidade latino-americana, que conformou laços efetivos e condensados de vários modos ao longo da história, e que ultrapassaram fronteiras nacionais e de seus próprios centros, atendendo a um "entramado" que privilegiou certas metrópoles, determinados textos e figuras, que operaram como agentes de integração. Cabe ressaltar que Zanetti partilha das considerações de Angel Rama, que na obra A Cidade das Letras demonstrou que no período anterior à independência havia uma extensa rede intelectual no continente conformada a partir da colônia, responsável pela administração colonial. Com efeito, a autora utiliza a palavra "religação" para se referir a tal aproximação (ZANETTI, 1994, p.491) e (RAMA, 1985, p.41-42).

${ }^{8}$ No final do século XIX surgiu na América Latina uma escola literária de grande renovação estética, conhecida como Modernismo, cujos poetas se configuraram como a primeira expressão de autonomia literária dos países hispano-americanos. Tal movimento procurava distanciar-se do "materialismo" da burguesia por meio de uma "arte mais refinada e estética". Na América hispânica o modernismo teve como precursor o poeta nicaraguense Rubén Darío, com a publicação de seu livro Azul (1888). Logo muitos pensadores influenciados por Darío se vincularam a este movimento, como o mexicano Gutiérrez Nájera, o argentino Leopoldo Lugones e os uruguaios Júlio Herrera y Reissig e José Enrique Rodó (TELLES, 1992) e (JOZEF, 2005, p.85).

9 A Guerra de independência cubana em 1898, a criação do Panamá em 1902, as conferências panamericanas $(1889 / 1890,1901,1910)$ os sucessivos desembarques de marines (em Cuba, Honduras, Nicarágua, Santo Domingo, tudo isso indicava a ingerência estadunidense no continente.
}

Revista Eletrônica da ANPHLAC, n. 13, p. 135-163, jul./dez. 2012.

http://revista.anphlac.org.br/index.php/revista 
de hegemonia que fora denunciado por Martí. Este último, ao alertar sobre o imperialismo norte-americano, acabou favorecendo a formação de correntes de oposição à política dos Estados Unidos em todo o continente.

As abruptas mudanças que as transformações oriundas do processo de modernização causaram na América Latina contribuíram para a constituição de respostas literárias e culturais semelhantes nos diferentes centros (ZANETTI, 1994, p.492-493). Conforme sustenta Zanetti, a modernização não definiu:

\begin{abstract}
(...) la constelación de artistas e intelectuales del periodo, pero fue condición imprescindible para que fuera posible un movimiento mancomunado en concepciones estéticas e ideológicas, para que surgiera el intercambio y la discusión entre pares, medianamente generalizada y con cierta simultaneidad. La religación, en sus numerosas variables, supone la quiebra del aislamiento, del compartimiento estanco, y para ello hacían bases materiales para vehiculizarla y una mentalidad moderna (ZANETTI, 1994, p.500).
\end{abstract}

Zanetti destaca como o principal agente de "religação" da época a imprensa, uma vez que esta promoveu uma ampla rede de conexões entre os latino-americanos. Desse modo, as crônicas, os relatos de viagem, o interesse pela arte e pela cultura tanto europeia quanto latino-americana em comum, favoreceriam o conhecimento de personalidades, modos de vida, panoramas e figuras típicas que, atrelados à informação política, social e econômica dos diferentes países, propiciariam a aproximação dos autores (ZANETTI, 1994, p. 514). Ao mesmo tempo, vários escritores/jornalistas atuavam como correspondentes na imprensa de outros países que não os seus - Ricardo Palma, Martí, Rodó, Gómez Carrillo, entre outros - ou trabalhavam em suas redações. Muitas revistas e diários foram criados por escritores que se encontravam exilados ou a trabalho, como foi o caso da Revista Venezolana (1881), editada por Martí na Venezuela.

Outro aspecto comum entre os escritores deste período é o fato de que possuíam múltiplas ocupações. Eram jornalistas, professores universitários, escritores, editores, ocupavam cargos diplomáticos, como Martí, e muitas vezes atuavam diretamente na política de seus países como foi o caso de Rodó. Este, inclusive, chegou a refletir sobre tais características da época elucidando em uma carta a Baldomero Sanín Cano, o panorama das especializações e da literatura como vocação dos intelectuais:

Revista Eletrônica da ANPHLAC, n. 13, p. 135-163, jul./dez. 2012.

http://revista.anphlac.org.br/index.php/revista 
Quizás no es usted ajeno a esta fatalidad de la vida sudamericana que nos empuja a la política a casi todos los que tenemos una pluma en la mano. Y yo no considero esto enteramente como un mal. Todo está en que no nos dejemos despojar de nuestra personalidad (RODÓ apud ROTKER, 1992, p.67).

Assim, observamos que os escritores deste período atuavam em um ambiente bastante propício à aproximação. Para Zanetti (1994, p.517-517) a característica mais importante desse processo de modernização, no âmbito intelectual, foram as "propostas comuns", que transformaram a América Hispânica, pela primeira vez, em uma arena compartilhada de solidariedade articulada para a defesa dos mesmos ideais.

As viagens também estimulavam o contato mais estreito entre a intelectualidade latino-americana. O translado de escritores tanto na América quanto na Europa produziria uma rede de vínculos entre eles que acabou contribuindo para que se reconhecessem e fossem reconhecidos como hispano-americanos. Paris era a principal referência para a intelectualidade latino-americana. Não obstante, após a guerra hispano-americana a Espanha desempenharia um papel similar ao da França como pólo extracontinental de reunião dessa intelectualidade. Já na América Latina, Buenos Aires foi, indubitavelmente, o centro aglutinador mais importante. Vários escritores do período passaram uma temporada na Argentina, como Ruben Darío, Miguel de Unamuno, Clorinda Matto e Carlos Amézada.

A partir dos anos de 1880, Nova York, operou como lugar privilegiado para reunir a intelectualidade latino-americana. Razões políticas empurraram vários intelectuais para lá: os porto-riquenhos Eugenio María Hostos, Ramón Emeterio Betances e Manuel Zeno Gandía; os cubanos José Martí, Enrique Piñeyro e Enrique José Varona; o costarriquense Manuel González Zeledón; e os venezuelanos Nicanor Bolet Peraza e César Zumeta.

Angel Rama chama a atenção para o cosmopolitismo que imperava na época e que favoreceu a ampliação dos agrupamentos literários que começaram a abarcar todo o Ocidente. De acordo com o autor, o projeto cultural culto foi "ardientemente cosmopolita", agregando as mais variadas literaturas modernas. Desde as literaturas nórdicas e germanas (Henrik Ibsen, Georg Brandes, Friedrich Nietzsche) e a norte- 
americana (Edgar Allan Poe e Walt Whitman). Além de literaturas passadas, como a greco-latina e orientais (RAMA, 1985, p.85-86).

Somando-se ao internacionalismo, promovido pelas viagens à Europa e aos Estados Unidos, ocorreu, conforme sublinhou Rama (1985, p.86), o que até então não se passara antes no continente: a intercomunicação da produção literária das diversas regiões hispano-americanas. Tal intercomunicação era propiciada tanto pelas muitas viagens dos intelectuais pelo continente (exilados ou a trabalho) como também, pelo surgimento de vários jornais, onde escreviam sobre a produção de seus colegas.

Numa época, em que os direitos autorais não eram levados em conta, os jornais que não podiam pagar as colaborações não deixavam de publicá-las por isso. Segundo Angel Rama (1985, p.86) os escritores toleravam essa prática a "regañadientes". Entretanto, encontramos queixas de Martí no que tange a publicação de suas crônicas por vários jornais que não se preocuparam em pagar por isso.

Assim, as sucessivas viagens dos escritores, o ativo intercâmbio epistolar, o jornalismo, a mudança literária, e as novas instituições que surgiam a partir das múltiplas transformações do período, asseguravam um espaço de liberdade jamais visto para a produção nos diferentes centros. De certa forma, isso repousava em uma materialização de fortes laços de solidariedade, cujo elemento aglutinador foi a reiterada afirmação do pertencimento latino-americano (ZANETTI, 1994, p.531). Nesse sentido, Martí e Rodó são os grandes precursores de um "pertencimento" que viria garantir a defesa de uma identidade latino-americana e que inspirou as gerações subsequentes.

\section{A identidade latino-americana}

Martí e Rodó voltaram suas atenções para a América Latina, mas diferente de grande parte dos seus contemporâneos, após refletirem sobre essa porção do continente, não apresentaram um diagnóstico condenatório em relação ao seu futuro. Pelo contrário, apesar de reconhecerem os problemas que a cercavam, apontaram soluções concretas e concluíram que a América estava "se salvando".

Susana Rotker (1992, p.9), na obra Fundación de una escritura, afirma que Martí pode ser considerado o precursor da redefinição da escrita jornalística e literária 
na América Latina, quando se tornou correspondente em Nova York dos principais diários hispano-americanos. Para a autora, a transformação na maneira de escrever que ocorreu nesse período e, por conseguinte os modos de percepção da realidade, foram tão significativos que o jornalismo acabou se tornando o veículo privilegiado dos primeiros textos latino-americanos.

A partir disso, os textos jornalísticos passaram a admitir novas formas de linguagem, apresentando uma escrita comprometida histórica e politicamente com a época. As crônicas, nesse sentido, operaram como meio de crítica e, ao mesmo tempo, de expressão da sociedade que se modernizava. Elas permitiram também a construção de uma poética que pela primeira vez se encontrava nos jornais e não nos livros e que foi se dando quase ao mesmo tempo em boa parte da América Latina (ROTKER, 1992, p.10).

Martí escrevia para inúmeros jornais latino-americanos e também estadunidenses. Foi observador atento das mudanças que a modernização trazia consigo e registrou suas impressões em diversos momentos. ${ }^{10}$ Também, teve uma preocupação que o acompanhou a maior parte da vida, a independência cubana, e a partir dos anos de 1880, as questões relativas à nuestra América.

Assim, apesar de Martí ter discursado muitas vezes em nome de Cuba, e escrito numerosos artigos sobre sua pátria, ele também discorrera a respeito de sua "pátria maior”. A América passaria a ocupar um lugar importante em seus escritos. Ele viveu muito tempo se dedicando a libertar Cuba do domínio espanhol, o que o obrigou a passar também a maior parte de sua vida adulta afastado da ilha. Viveu na Europa, México, Venezuela e Estados Unidos, além de viajar para outros países da América, o que lhe permitiu estabelecer relações estreitas com muitos intelectuais, não só latinoamericanos como estadunidenses e europeus, e divulgar seus escritos.

Nuestra América surgia num cenário em que circulavam e prevaleciam as representações do continente latino-americano como um "corpo enfermo", corrompido pela mistura racial e pela sobrevivência de etnias e culturas tradicionais, supostamente

\footnotetext{
${ }^{10}$ Em várias crônicas encontramos as observações de Martí a respeito do processo de modernização nos Estados Unidos. O escritor cubano se dedicou também a narrar vários aspectos da vida norte-americana que observara no período em que viveu em Nova York. Posteriormente, suas crônicas, sobre a sociedade estadunidense de fins do século XIX, foram recolhidas sob o título de Escenas norteamericanas.
}

Revista Eletrônica da ANPHLAC, n. 13, p. 135-163, jul./dez. 2012.

http://revista.anphlac.org.br/index.php/revista 
determinadas a submergir no devir do progresso e da modernização (RAMOS, 2008, p.269). Tal maneira de interpretar a realidade da América Latina estava intimamente relacionada às teorias racistas europeias que aliadas ao desenvolvimento científico da época, permitiram que os preconceitos raciais que já existiam desde a época colonial fossem validados cientificamente (MITRE, 2010, p.214). Com efeito, autores como Arthur de Gobineau, Gustave Le Bon e Cesare Lombroso se tornaram moedas correntes no continente (STEPAN, 2005, p.50). Suas ideias influenciaram significativamente o pensamento latino-americano na virada do XIX para o XX, e estimularam estudos que acabaram na sua maioria atribuindo ao continente uma "condição patológica". 11

Martí, frente a isso, reafirmou uma identidade comum americana (latinoamericana) e a partir disso procurou meios de fortalecer tal identidade, começando por incentivar o conhecimento mútuo entre os povos do continente, e a necessidade de deixar as diferenças de lado. Durante muito tempo as relações entre as nações latinoamericanas não haviam sido amigáveis, conflitos principalmente fronteiriços, levaram a guerras, em determinados momentos devastadoras, entre alguns países da América. Conforme mencionamos, ao longo do século XIX foram vários os conflitos envolvendo aquelas nações. Martí ((1980, p.126-127)) advertia que "los pueblos que no se conocen han de darse prisa para conocerse", nesse sentido era necessário que as disputas dessem lugar a união entre os que compartilhavam uma mesma cultura.

Quando Martí conclamou a nuestra América, se referia aos países que dividiam um mesmo legado cultural, não apenas por serem procedentes da tradição ibérica, mas por possuírem também populações que traziam nas veias o sangue de vários povos e que sofreram igualmente séculos de exploração colonial por metrópoles europeias. Não desprezou os indígenas, pelo contrário, valorizou sua cultura e escreveu artigos ressaltando a grandiosidade de povos como os astecas e os incas.

\footnotetext{
${ }^{11}$ Destacamos algumas obras produzidas neste viés como: Manual de Patología Política (1889) do argentino Juan Alvarez; El Continente Enfermo (1899) do venezuelano César Zumeta; America Latina: males de origem (1903) do brasileiro Manoel Bomfim; Enfermedades Sociales (1905) do argentino Manuel Ugarte; Los negros brujos (1906) do cubano Fernando de Ortiz; Pueblo Enfermo (1909) do boliviano Alcides Arguedas; Nuestra América: ensaio de psicología social (1911) do argentino Carlos Octavio Bunge; La enfermedad de Centroamérica (1912) do nicaraguense Salvador Mendieta; Nuestra inferioridad económica (1912) do chileno Francisco Encinas; e Las democracias Latinas de América (1912) do peruano Francisco García Calderón.
}

Revista Eletrônica da ANPHLAC, n. 13, p. 135-163, jul./dez. 2012. http://revista.anphlac.org.br/index.php/revista 
Na contramão do que comumente se fazia na época, Martí valorizou as tradições autóctones. Não escondeu nem condenou a conformação dos povos latino-americanos. No artigo "Las Ruinas Indias", discorreu sobre os vários povos indígenas que habitaram a América pré-colombiana comparando-a com a civilização ocidental. Nessa direção, salientou que tanto uma civilização quanto a outra fora capaz de alcançar o desenvolvimento, ter atitudes nobres e louváveis, bem como atitudes terríveis. Nesse intuito, sublinhou, para fazer um paralelo com a civilização ocidental, que os sacrifícios humanos dos astecas poderiam ser comparados à inquisição praticada pela Igreja Católica.

Martí, que inegavelmente possuía um olhar diferenciado dos seus contemporâneos acerca da realidade do continente, percebeu e denunciou os perigos que cercavam a América além da metrópole ibérica. A proposta de uma unidade latinoamericana poderia, naquele momento, operar como uma barreira mais eficaz - do que uma pequena ilha que ainda não conseguira se desvencilhar dos grilhões da colonização -, frente ao avanço estadunidense.

Nessa direção, no artigo Nuestra América, o escritor cubano defendeu terminantemente a valorização do que era específico da América Latina. Uma das características dos seus escritos é a constante presença de metáforas que aludem a situações simples, mas com profunda capacidade ilustrativa. Martí as empregava para tratar de temas envolvendo a realidade do continente, um exemplo é o ataque que fez àqueles latino-americanos que viviam fora de seus países e que se envergonhavam da pátria miscigenada. A esse respeito afirmara:

¡Estos hijos de carpintero, que se avergüenzan de que su padre sea carpintero! ¡Estos nacidos en América, que se avergüenzan porque llevan delantal indio, de la madre que los crió, y reniegan, ¡bribones!, de la madre enferma, y la dejan sola en el lecho de las enfermedades! Pues, ¿quién es el hombre?, ¿el que se queda con la madre, a curarle la enfermedad, o el que la pone a trabajar donde no la vean y vive de su sustento en las tierras podridas, con el gusano de corbata, maldiciendo del seno que lo cargó, paseando el letrero de traidor en la espalda de la casaca de papel? (MARTÍ, 1980, p.128)

Assim, Martí, através de metáforas que aludiam à ideia de uma família latinoamericana, fundamentava seu discurso, justificando a necessidade dos latino-americanos se perceberem como uma família e, consequentemente, trabalharem em prol da 
superação dos problemas. Para tanto, haveria que enfrentar dois grandes inimigos: os "tigres de dentro" e os "tigres de fora". Os primeiros seriam os próprios latinoamericanos, imbuídos do positivismo de fins do século XIX, e impressionados com o desenvolvimento que alguns países europeus e os Estados Unidos haviam experimentado, defendendo a importação de seus modelos desconsiderando e mesmo refutando a especificidade da América. Os "tigres de fora" seriam representados pelos Estados Unidos.

Martí reconhecia os problemas que cercavam a América, a começar por fatores internos, como a importação excessiva de fórmulas alheias. Criticava o modo como muitos governantes pretendiam conduzir o destino de suas nações, e advertia:

(...) el buen gobernante en América no es el que sabe cómo se gobierna el alemán o el francés, sino el que sabe con qué elementos está hecho su país, y cómo puede ir guiándolos en junto, para llegar, por métodos e instituciones nacidas del país mismo, a aquel estado apetecible donde cada hombre se conoce y ejerce, y disfrutan todos de la abundancia que la Naturaleza puso para todos en el pueblo que fecundan con su trabajo y defienden con sus vidas (MARTÍ, 1980, p.129).

$\mathrm{O}$ escritor cubano no intuito de mostrar como era infundado tal posicionamento discorrera sobre a história da América, que mesmo submetida a séculos de exploração colonial, ainda tirara forças para lutar pela independência. Segundo ele: “(...) no hay patria en que pueda tener el hombre más orgullo que en nuestras dolorosas repúblicas americanas” (MARTÍ, 1980, p.131). Martí exaltava o continente, assinalando que nunca havia se formado, em tempo histórico, nações tão adiantadas e compactas provenientes de fatores tão complexos e corrompidos.

Aquele era o momento de mudar, a América Latina deveria regenerar. Para Martí a incapacidade ou a dificuldade não estava em governar repúblicas jovens que ainda se encontravam em formação, mas em reger povos originais com leis importadas de lugares e realidades distintas do continente. Era fundamental levar em consideração a singularidade dos povos latino-americanos, pois a simples transferência de leis e práticas de outras realidades conduziria a grandes erros. A solução para os problemas da América Latina estava no olhar introspectivo, no seu auto-entendimento e autoavaliação para compreender o que lhe era mais necessário e adequado.

Revista Eletrônica da ANPHLAC, n. 13, p. 135-163, jul./dez. 2012.

http://revista.anphlac.org.br/index.php/revista 
Assim, não bastava saber sobre a história da Grécia, conhecer as leis que regiam a Alemanha, a Inglaterra ou a França, se a realidade da América exigia regulamentos específicos. Com efeito, Martí ressaltou que o governo deveria ater-se nas questões de seu próprio país. Era o equilíbrio dos elementos naturais do país que garantiria o bom governo e seu desenvolvimento.

Para que isso ocorresse, era necessário que as universidades latino-americanas passassem a ensinar o original da arte do governo, isto é, a análise dos elementos característicos dos povos da América Latina. Por isso, censurava a elite letrada da América, que ao terminar seus estudos nas universidades norte-americanas e francesas onde aprendiam história e leis que não eram as de seus países -, retornavam com ambições de governar algo que não conheciam, questionando e tentando intervir em uma realidade que ignoravam. Além disso, ainda importavam soluções que não eram compatíveis com as necessidades do continente. Daí Martí assinalar que a carreira política deveria ser vetada aos que não conheciam o rudimentar da política, uma vez que:

Resolver el problema después de conocer sus elementos, es más fácil que resolver el problema sin conocerlos. Viene el hombre natural, indignado y fuerte, y derriba la justicia acumulada de los libros, porque no se la administra en acuerdo con las necesidades patentes del país. Conocer es resolver. Conocer el país, y gobernarlo conforme al conocimiento, es el único modo de librarlo de tiranías (MARTÍ, 1980, p.130-131).

Nessa perspectiva, a história latino-americana deveria ser priorizada, os incas haveriam de ser mais conhecidos, mesmo que fosse em detrimento do estudo dos arcontes gregos. "Nuestra Grecia es preferible a la Grecia que no es nuestra. Nos es más necesaria”. Os políticos nacionais deveriam substituir os exóticos, o mundo deveria ser conhecido, mas “el tronco ha de ser el de nuestras republicas” (MARTÍ, 1980, p.131). Outra crítica apontada por Martí se refere ao fato de que após a independência, embora houvesse ocorrido uma mudança na forma política, o espírito não mudara. Isso fez com que, segundo o autor, a colônia sobrevivesse na república. ${ }^{12}$

\footnotetext{
${ }^{12}$ No século XIX essa foi uma crítica bastante comum de publicistas como Sarmiento e Alberdi que consideravam que, após os processos de independência, os jovens estados prontamente teriam tomado uma forma assemelhada a dos estados metropolitanos, dando uma impressão de continuidade, por detrás de uma máscara de ruptura.
}

Revista Eletrônica da ANPHLAC, n. 13, p. 135-163, jul./dez. 2012.

http://revista.anphlac.org.br/index.php/revista 
A América, na concepção de Martí, poderia vislumbrar um futuro otimista, pois, apesar das dificuldades oriundas de um passado colonial ela era capaz de erigir palácios, dominar a natureza, desenvolver a imprensa, fazer estradas de ferro, enfim, tudo o que as nações desenvolvidas alcançaram. No discurso proferido no sarau artístico-literário da sociedade literária hispano-americana, em dezembro de 1889, assistido pelos delegados da Conferência Internacional Americana, Martí salientou a história da América, ressaltando a diferença entre o processo colonizador da América do Norte e o da "nuestra América". De acordo com o autor nossa América também:

(...) con el Sol en la frente, surge sobre los desiertos coronada de ciudades. Y al reaparecer en esta crisis de elaboración de nuestros pueblos los elementos que lo constituyeron, el criollo independiente es el que domina y se asegura, no el indio de espuela, marcado de la fusta, que sujeta el estribo y le pone adentro el pie, para que se vea de más de alto a su señor (MARTÍ, 1980, p.123-124).

A tarefa de transformar a América não era fácil, havia muito trabalho a ser feito. O quadro do continente até então era de fragmentos que interagiam de forma anárquica e inclinados à dispersão, uma vez que, conforme sublinhava Martí:

Éramos una visión, con el pecho de atleta, las manos de petimetre y la frente de niño. Éramos una máscara, con los calzones de Inglaterra, el chaleco parisiense, el chaquetón de Norteamérica y la montera de España (MARTí, 1980, p.134).

Logo a América não possuía uma unidade, pois ao longo dos tempos fora "desarticulada" e depois constituída com os remanescentes de regulamentos e fragmentos contraditórios de tradições em luta, sendo fruto de uma violência histórica, de uma amputação das "origens confusas e manchadas de sangue" (RAMOS, 2008, p.265).

Teria sido formidável, de acordo com Martí, se a "caridade do coração e a ousadia dos fundadores" tivessem sido unidas. Se o índio e o negro tivessem sido incorporados à sociedade e lhes fosse permitido compartilhar da liberdade que lutaram para conquistar. Nem o livro europeu nem o ianque foram capazes de desvendar o enigma hispano-americano. As rivalidades e o ódio apareceram e os países pioraram cada vez mais. Porém, segundo Martí (1980, p.199): “cansados del odio inútil (...) se 
empieza, como sin saberlo, probar el amor (...) el pensamiento empieza a ser de América".

Assim, a América estava mudando, ou como afirmava o escritor cubano, "estava se salvando", existia a possibilidade de um porvir otimista, já que o que designava de "gênio da moderação" estava ganhando espaço na América, mediante a harmonia da natureza e a influência de leituras críticas provenientes da Europa que penetrara na geração anterior e que permitia o nascimento na América do "hombre real" (MARTÍ, 1980, p.134). Portanto, se por um lado Martí condenava a transposição irrefletida de leis e soluções para a América Latina, por outro, incentivava a preparação por meio de leituras críticas visando desenvolver o continente a partir de suas necessidades.

O cenário no qual Ariel foi gestado diz respeito à modernização cada vez mais evidenciada pelas inúmeras novidades que apareciam na virada do século XIX para o XX. O quadro político também se alterava significativamente, já que os Estados Unidos, com a vitória sobre a Espanha em 1898, despontavam como potência imperialista e passavam a intervir diretamente no Caribe. O cientificismo positivista indicava que não era capaz de responder às questões que se impunham à América (OLIVEIRA, 2005, p.112). Diante disso, o Ariel, com sua mensagem idealista e em oposição ao utilitarismo norte-americano, repercutiu profundamente entre a intelectualidade latino-americana.

O Ariel foi escrito em linguagem erudita, repleta de metáforas, porém, mais complexas que as empregadas por Martí. Fazia críticas ao cientificismo positivista e procurava recuperar o idealismo numa perspectiva romântica, defendendo uma aristocracia de espírito ao mesmo tempo em que uma liderança comprometida com o bem público (OLIVEIRA, 2005, p. 112).

A obra inicia fazendo uma alusão aos personagens shakespearianos, quando o sábio mestre Próspero encontra-se com seus jovens discípulos para despedir-se após um ano de estudos. O encontro se dá em uma grande sala, repleta de livros e na qual há uma estátua de bronze representando Ariel, definido pelo escritor uruguaio como sendo o: “império da razão e dos sentimentos sobre os baixos estímulos da irracionalidade". Ele é também "o entusiasmo generoso, o móvel elevado e desinteressado na ação, a espiritualidade da cultura; a vivacidade e a graça da inteligência” (RODÓ, 1991, p.13).

Revista Eletrônica da ANPHLAC, n. 13, p. 135-163, jul./dez. 2012.

http://revista.anphlac.org.br/index.php/revista 
Próximo à estátua e após invocar Ariel como seu espírito protetor, Próspero começava a discursar para os discípulos que o escutavam atentamente. O objetivo era salientar o aprendizado de todo o ano. O mestre fazia ponderações sobre várias questões que envolviam a América e o seu porvir e destacava o papel precursor da juventude na orientação do presente latino-americano.

O ensaio Ariel procurava assim, trazer uma mensagem para a América e para a sua juventude. Rodó indicava, em meio a tantas conjeturas pessimistas em relação ao futuro da América Latina que, caminhos a poderiam levar a um porvir favorável. Seu discurso não se limitava ao Uruguai, e tampouco à região rio-platense - que na época apresentava boas possibilidades de desenvolvimento devido ao processo de modernização que vinha experimentando -, mas buscou abranger a maior parte do continente.

O autor de Ariel tomou partido na defesa da preservação do que considerou ser a singularidade latino-americana; singularidade esta em que se encontrava ameaçada pela admiração que muitos dos seus contemporâneos estavam nutrindo pelos Estados Unidos. Rodó, assim, alertava que:

\footnotetext{
Costuma-se comentar nos tratados de ética um preceito moral de Cícero, segundo o qual faz parte dos deveres humanos que cada um de nós cuide e conserve zelosamente a originalidade de seu caráter pessoal, o que nele existe que o diferencie e determine, respeitando, em tudo o que não seja inadequado ao bem, o impulso primário da Natureza, que fundou na distribuição variada de seus dons a ordem e a harmonia do mundo (RODÓ, 1991, p.72).
}

$\mathrm{O}$ autor uruguaio temia, pois que a admiração que muitos intelectuais e políticos no continente sentiam pelos Estados Unidos conduzisse a uma descaracterização dos povos latino-americanos. Para alguns de seus contemporâneos, de acordo com ele, esta dita peculiaridade latino-americana nem era uma realidade, visto que o continente, sendo composto por variados povos, não possuía nenhuma "marca própria e definida por cuja permanência e integridade se [devesse] lutar” (RODÓ, 1991, p.72). Mas, Rodó contestava tal fato e argumentava, com insistência, que a América possuía sua singularidade. Esta se encontraria, nas palavras do autor: "na herança de raça, uma tradição étnica a manter, um vínculo sagrado que nos une a páginas imortais da História, confiando à nossa honra sua continuidade no futuro" (RODÓ, 1991, p.72).

Revista Eletrônica da ANPHLAC, n. 13, p. 135-163, jul./dez. 2012.

http://revista.anphlac.org.br/index.php/revista 
A educação tinha nisso, um papel fundamental. Era vista por muitos intelectuais à época - inclusive Martí - como um dos principais caminhos que levariam à transformação da América. Entretanto, segundo Rodó, ela não deveria ser implementada com vistas a corrigir os traços de caráter das sociedades que, naquele momento, precisavam adaptar-se às novas exigências da civilização e às novidades oriundas do progresso e da modernização (RODÓ, 1991, p.70).

Rodó percebia que esse processo já estava em curso, e que, no entanto, deveria ocorrer de modo a equilibrar a influência inovadora e a força da tradição. Ele destacava ainda os vários perigos que poderiam sobrevir com o desígnio de desnaturalizar o caráter dos povos, isto é, com a ânsia de transplantar modelos estranhos imolando a “insubstituível originalidade de seu espírito, na crença ingênua de que se possa alguma vez obtê-lo com procedimentos artificiais e improvisados de imitação". Tal importação despropositada não traria resultados benéficos para a América, pois não possuía "raízes na Natureza nem na História” (RODÓ, 1991, p.71).

Rodó percebia a herança latina/ibérica como o traço mais característico da América Latina e era exatamente este que deveria ser preservado. Mesmo que os novos tempos exigissem a incorporação de mudanças, como, por exemplo, no caso do Uruguai que recebia um intenso afluxo de imigrantes à época, isso não significava que o passado devesse ser negado e nem a herança de "raça" desprezada. Pelo contrário, dever-se-ia conciliar a modernidade com a tradição, pois para o escritor era precisamente a fusão dos novos elementos com a "raça" existente que constituiria "o definitivo americano do futuro" (RODÓ, 1991, p.72).

A competição, nessa perspectiva, passava a ser vista como algo favorável. Conforme sustentava Rodó, as evoluções da História, os períodos mais criativos cujo desenvolvimento da humanidade se fez notar com mais energia, foram os momentos em que duas forças distintas e coexistentes competiam arduamente, mantendo o estímulo que levava a busca pelo desenvolvimento e o aperfeiçoamento.

Nesta concepção de Rodó, a disputa de gênios não eliminava, mas admitia e sob numerosos aspectos até favorecia, a concórdia e a solidariedade. Era a influência recíproca que poderia conduzir a um futuro glorioso para ambas as partes que competiam (RODÓ, 1991, p.73). Mas não a sobreposição de uma sobre a outra. Para

Revista Eletrônica da ANPHLAC, n. 13, p. 135-163, jul./dez. 2012.

http://revista.anphlac.org.br/index.php/revista 
que isso não ocorresse, caberia à juventude orientar as transformações que levariam à efetiva regeneração da América Latina. Contudo, essa regeneração só poderia ocorrer se estivesse associada à tradição ibérica - elemento, para Rodó, característico da identidade latino-americana.

\section{A juventude e o seu papel no futuro da América Latina}

Para Martí e Rodó a América Latina estava se "salvando" e a juventude deveria conduzir as mudanças que permitiriam a sua redenção. Caberia aos jovens com sua força renovadora trabalhar em função do continente. Assim entrava em cena o papel revigorante e inovador da juventude, que fora bastante ressaltado na época. Aquele era o momento em que caberia aos jovens criar.

Nessa perspectiva, era imprescindível à América revelar-se como realmente era, conhecer-se e dar-se a conhecer seria uma das suas principais tarefas. Contudo, de acordo com Martí, era preciso "conectar a alma e a intenção", para que houvesse a vitória sob um passado asfixiante. Essa mudança, para o escritor cubano e o uruguaio, estava sendo levada a cabo pela mesma juventude que deveria tomar para si o destino da América Latina, ainda que tal porvir fosse sonhado diferentemente pelos dois autores.

Na opinião de Martí a América começava a se dar conta da excessiva imitação em que havia mergulhado durante tanto tempo. $\mathrm{O}$ importante naquele momento era "criar". Para ele, já se tornava claro que as formas de se governar um país deveriam adequar-se aos seus elementos originais, que as ideias absolutas teriam que ser relativizadas para não resultarem em erros de forma, e que a liberdade para ser possível teria que ser verdadeira e integral, pois, para o escritor cubano, a república só continuaria existindo se se tornasse realidade para todos. Segundo ele:

Los jóvenes de América se ponen la camisa al codo, hunden las manos en la masa, y se levantan con la levadura de su sudor, entienden que se imita demasiado, y que la salvación está en crear. Crear es la palabra de pase de esta generación. El vino de plátano; y si sale agrio, jes nuestro vino! (MARTÍ, 1980, p.135)

Revista Eletrônica da ANPHLAC, n. 13, p. 135-163, jul./dez. 2012.

http://revista.anphlac.org.br/index.php/revista 
Era o momento de se tentar o novo, a possibilidade de cometer erros não era pequena, mas o que importava era que finalmente a originalidade estava em primeiro plano. Dessa forma as críticas também deveriam ser constantes, pois eram saudáveis e estimulavam a busca pelo melhor. Todavia, elas deveriam vir na mesma sintonia, visando o desenvolvimento mútuo. Na concepção de Martí, a América estava assumindo o seu destino, surgiam governantes naturais do estudo direto da natureza; se liam, era para aplicar, e não para copiar. Os economistas passavam a apreender a dificuldade em suas origens. A arte voltava as atenções para as características mais originais, "los gobernadores, en las repúblicas de indios, aprenden indio" (MARTÍ, 1980, p.136).

Para Martí, eram exatamente o espírito crítico, a consciência de que se imitava demasiado e a criatividade que estavam fazendo a diferença e levando à transformação da América. Impulsividade, crítica e anseio pela novidade seriam as características por ele apreciadas e atribuídas à juventude na época.

Nas primeiras páginas de Ariel, Rodó justificara as razões que o tinham levado a eleger a juventude como a grande protagonista na transformação almejada. Para o escritor, o espírito da juventude se constituía em "terreno generoso onde a semente de uma palavra oportuna costuma gerar, em pouco tempo, os frutos de uma imortal vegetação" (RODÓ, 1991, p.15).

O Ariel trazia uma mensagem alentadora para a juventude latino-americana que deveria conduzir o futuro da América Latina. Através de suas metáforas, prenhes de referências à história grega ou à literatura europeia, Rodó, emprestava suas palavras a Próspero, e discursava à juventude. O seu discurso ao longo da obra assumiu contornos variados. Em determinados momentos vinha em forma de conselhos, em outros de censuras, questionamentos, advertência ou exaltação. Entretanto, o objetivo de imprimir no espírito dos jovens a responsabilidade que lhes cabia no porvir da América Latina, perpassa todo o Ariel.

As razões postuladas por Rodó para que seu discurso fosse direcionado à juventude são muitas. $\mathrm{O}$ escritor uruguaio partia da premissa de que a juventude trazia consigo algumas características inerentes à sua condição: força, impaciência da ação, entusiasmo, e sonhos. Muitas vezes alimentados por histórias fantásticas envolvendo 
lugares extraordinários, como Cipango e Eldorado - seriam com esses instrumentos que transformariam a realidade naquele momento.

A juventude, portadora do futuro, fora escolhida para reverter a situação da América. Em uma dada passagem, Rodó (1991, p.16), inspirado nos escritos de Jean Marie-Guyau (1854-1888), ressaltava que a humanidade "renovando de geração em geração sua ativa esperança e sua ansiosa fé num ideal através da dura experiência dos séculos", podia ser comparada à loucura:

\begin{abstract}
A obsessão daquela pobre insana cuja estranha e comovente loucura consistia em acreditar constantemente que chegara o dia de suas bodas. Joguete de seu sonho, todas as manhãs ela cingia sua fronte pálida com a coroa de casamento e colocava em sua cabeça o véu nupcial. Com um doce sorriso, preparava-se a seguir para receber o ilusório noivo, até as sombras da tarde, depois da vã espera, traziam-lhe a decepção à alma. Sua loucura, então, assumia um tom melancólico. Mas sua ingênua confiança ressurgia com a aurora seguinte, e sem mais recordar o desencanto passado, murmurando é hoje que ele virá, tornava a cingir a coroa e o véu, e a sorrir à espera do noivo (RODÓ, 1991, p.16-17).
\end{abstract}

Na opinião de Rodó, com a humanidade se passava o mesmo, já que assim que um ideal perdia sua força se mostrando ineficaz, ela [a humanidade] colocava suas "galas nupciais" mais uma vez para esperar a realidade do ideal sonhado com nova confiança.

Despertar essa constante renovação era o papel da juventude. Grande responsável pelas transformações pelas quais a América Latina necessitava passar, a juventude no Ariel ganhava conotações abstratas, passava a significar luz, amor e energia na alma dos indivíduos e das gerações. Para Rodó (1991, p.18), aos povos que mantinham consigo os atributos da juventude sempre lhes seriam possível dominar a fecundidade, a força e o porvir.

Com tanta responsabilidade, era necessário que a juventude tivesse consciência do seu valioso tesouro - a força sagrada que existia no seu interior. Este poderia ser usado para o bem ou não, e disso dependeriam as ideias que norteariam suas atitudes (RODÓ, 1991, p.20-21). Daí também a importância de uma orientação sábia para os jovens.

Estas palavras de estímulo à juventude estavam fortemente relacionadas à situação inquietante pela qual passava a América Latina. Por um lado, a condição

Revista Eletrônica da ANPHLAC, n. 13, p. 135-163, jul./dez. 2012.

http://revista.anphlac.org.br/index.php/revista 
complexa que muitos países latino-americanos enfrentavam - como o atraso econômico e social e a instabilidade política decorrente das disputas de lideranças locais -, abasteciam as interpretações pessimistas quanto ao futuro do continente. Por outro lado, Rodó elucidava que essa conjuntura, poderia, paradoxalmente, gerar uma situação favorável. Isso seria possível porque, a despeito de tudo indicar que tal situação levaria a uma renúncia e à condenação da existência, a insatisfação com a realidade poderia fomentar o desejo de renovação.

Por isso Rodó louvava a juventude. Considerava que essa fé era algo inerente a ela. Tal confiança não precisava ser ensinada, pois ela era um instinto, que se deixado atuar, seria rapidamente encontrado. O autor elucidando mais uma vez esta sua opção, destacava o porquê do seu interesse pela orientação moral do espírito juvenil:

\begin{abstract}
A energia de vossa palavra e de vosso exemplo pode chegar a incorporar as forças vivas do passado à obra do futuro. Penso com Michelet que o verdadeiro conceito da educação abarca não só o cultivo do espírito dos filhos pela experiência dos pais, mas também, e com frequência muito mais, o cultivo do espírito dos pais pela inspiração inovadora dos filhos (RODÓ, 1991, p.26).
\end{abstract}

O presente aparecia numa condição delicada para Rodó. $\mathrm{O}$ autor concebia que a filosofia no trabalho e no combate deveria estar apartada do presente, uma vez que este só era necessário na medida em que operava como "degrau onde se poderia firmar o pé" (RODÓ, 1991, p.102). O futuro era o que realmente importava, mas esse somente seria favorável se as atitudes do presente fossem as corretas. Não era a vitória definitiva que deveria ser esperada, mas sim a obtenção das melhores condições de luta. Rodó ainda dizia que:

Talvez seja uma esperança ousada e ingênua crer numa aceleração tão contínua e feliz da evolução, numa eficácia tal de vosso esforço que o tempo concedido à duração de uma geração humana seja suficiente para elevar as condições da vida intelectual na América do grau incipiente em que agora se encontram à categoria de um verdadeiro interesse social e a um ápice que realmente domine (RODÓ, 1991, p.103).

De toda forma, se a transformação não podia ser completa, a tentativa do primeiro passo já seria uma grande conquista. E mesmo que os resultados não pudessem ser vistos pela geração que os disseminou, ainda assim não era motivo para se desistir

Revista Eletrônica da ANPHLAC, n. 13, p. 135-163, jul./dez. 2012. http://revista.anphlac.org.br/index.php/revista 
da transformação. Para Rodó a "melhor obra é a que se realiza sem as impaciências do êxito imediato, o mais glorioso esforço é o que coloca a esperança além do horizonte visível". O caminho a percorrer era longo, mas a recompensa final seria valiosa.

\section{Martí e Rodó: aproximações e particularidades}

A preocupação em relação ao futuro foi constante na América desde meados do século XIX, foram muitos os intelectuais que indicaram caminhos para que o continente ascendesse ao mundo civilizado e ao progresso. A inabilidade de lidar com as sociedades existentes, aliada à dificuldade de encontrar espaço na sociedade capitalista que se expandia, contribuíram para que as correntes modernizadoras surgidas no período considerassem que a história e o passado não mereciam necessariamente ser usados na consolidação desses estados nacionais (OLIVEIRA, 2005, p.111). Com efeito, tais correntes, influenciadas pelo positivismo, defenderam que para a América alcançar o progresso era sim necessário remover os obstáculos deixados pelo passado e impor modelos prontos e definidos (SANTOS, 2004, p.11).

Foi nesse contexto que Martí e Rodó, fazendo oposição às correntes modernizadoras que desconsideravam a singularidade da América Latina, produziram seus discursos. Ambos rechaçaram a importação de ideias e modelos pré-determinados e incentivaram o olhar introspectivo para a nossa América. As especificidades foram ressaltadas em suas obras, não para serem condenadas e desprezadas, e sim para serem valorizadas.

Os dois autores também construíram seus conceitos de América em oposição aos Estados Unidos e atribuíram à juventude o grande papel na transformação do continente. Os discursos de Martí e Rodó tiveram desdobramentos importantes, como a imagem de que um "novo mundo" e um "novo homem" estavam surgindo, revigorados pela energia da juventude e sua força criadora (WASSERMAN, 2004, p.142). Entretanto, apesar das semelhanças de seus discursos, que os aproximam, sem dúvida, são as particularidades os seus aspectos mais significativos e que nos auxiliarão melhor, no sentido de uma compreensão da forma como cada autor pensou a América Latina.

Revista Eletrônica da ANPHLAC, n. 13, p. 135-163, jul./dez. 2012.

http://revista.anphlac.org.br/index.php/revista 
Os contextos nos quais seus discursos foram gestados são muito distintos. Martí, proveniente de uma sociedade ainda colonial, possuía um olhar diferenciado em relação às questões que envolviam o continente. Foi sensível à situação degradante à qual negros e indígenas estavam submetidos, e em sua proposta de um "novo mundo", não rechaçou a presença e participação destes povos.

É válido lembrar que à época em que Martí estava escrevendo tal posição era bastante incomum. Negros e índios haviam sido suprimidos da maioria dos projetos de nação bem sucedidos ou em construção na maior parte dos países latino-americanos, até mesmo naqueles que possuíam uma população majoritariamente formada por indígenas, como era o caso da Bolívia. Tais povos não estiveram associados aos ideais de civilização e progresso que vigoravam na época, e eram simplesmente rejeitados na maioria dos projetos. Para resolver este "problema" - de excessivos indivíduos incompatíveis com a sociedade almejada - surgiram várias propostas visando a transformação da população latino-americana, dentre elas a de "branqueamento" progressivo através da vinda de imigrantes europeus, do retorno dos descendentes de escravos à África, e mesmo do extermínio dos indígenas. ${ }^{13}$

As críticas de Martí, no que tange ao continente, eram dirigidas principalmente à elite governante que olhava demasiado para o exterior e ignorava as questões de dentro. Não lamentou a conformação da população, ou associou o atraso da América Latina a isso, mas às duras condições que lhe foram impostas desde a colonização.

Além disso, Martí também percebia nos discursos colonizadores, "[d]os tigres de dentro", a causa da enfermidade do continente. Em Nuestra América, a desordem não era vista como resultado da "barbárie" ou da ausência da modernização. A degeneração da América era vista como produto da marginalização das culturas tradicionais em relação ao espaço da representação política. De acordo com Julio Ramos, Martí propunha em seu discurso a construção de um "nós" feito justamente com os elementos

\footnotetext{
${ }^{13} \mathrm{Na}$ época surgiram algumas propostas de extermínio da população indígena, associada à barbárie e percebida como um obstáculo para o desenvolvimento dos países hispano-americanos. Muitos, inspirados em tal política que já havia sido implementada nos Estados Unidos e na Argentina, pelo General Rocca "na conquista do deserto", chegaram a fazer afirmações nesse viés. José Manuel Pando, influenciado pelo darwinismo social de fins do século XIX, quando presidente da Bolívia (1899-1904), anunciou, por exemplo, a respeito dos indígenas, que não se deveria fazer esforços para educar esses "seres inferiores, cuja eliminação não seria um delito", mas uma maneira de adiantar a "seleção natural" (MITRE, 2010, p. 215).
}

Revista Eletrônica da ANPHLAC, n. 13, p. 135-163, jul./dez. 2012.

http://revista.anphlac.org.br/index.php/revista 
excluídos pelos discursos dos estados modernizadores. Ou seja, pelo: “índio mudo", o "negro aviltado", o camponês marginalizado pela "cidade desdenhosa"; uma vez que o "homem natural", não sendo incorporado ao projeto do ser nacional, "no espaço do bom governo", o derrubaria e governaria (RAMOS, 2008, p.269-270). Segundo Martí (1980, p.131): "Viene el hombre natural, indignado y fuerte, y derriba la justicia acumulada de los libros, porque no se la administra en acuerdo con las necesidades patentes del país."

Martí, diferente dos seus contemporâneos intelectuais, não se deixou influenciar pelos discursos racialistas e pseudocientíficos da época e negou de forma veemente a existência das raças como um dado apriori. Em "Mi Raza" o autor discorreu acerca da palavra racista, e procurou mostrar como era confusa e, por conseguinte, deveria ser esclarecida. Segundo ele "el hombre no tiene ningún derecho especial porque pertenezca a una raza u otra: dígase hombre y ya se dicen todos los derechos" (MARTÍ, 1963, p.298). É interessante destacar que nesse texto, Martí faz algumas afirmativas que somente seriam incorporadas nos discursos oficiais muito mais tarde, em fins do século $\mathrm{XX}$ e início do atual. Um exemplo que destacamos é que a igualdade entre brancos e negros para Martí era inquestionável:

Todo lo que divide a los hombres, todo lo que los especifica, aparta o acorrala, es un pecado contra la humanidad (...) Insistir en las divisiones de raza, en las diferencias de raza, de un pueblo naturalmente dividido, es dificultar la ventura publica, y la individual, que están en el mayor acercamiento de los factores que han de vivir en común (MARTÍ, 1963, p.298).

Temos que levar em conta que a conjuntura na qual Martí operava não abria espaço para o discurso do autóctone e do negro. ${ }^{14} \mathrm{O}$ estado não era receptivo a isso, ao contrário, as proposições modernizadoras associavam exatamente estas populações ao atraso.

Assim, conforme assinala Julio Ramos, foi a partir dos escritos do intelectual cubano que os indígenas puderam, já no século XX, ganhar uma legitimidade que concederia aos setores da literatura latino-americana uma grande autoridade social, até

\footnotetext{
${ }^{14}$ As considerações do teórico francês Gustave Le Bon possuíam grande força de afirmação tanto na Europa como na América. Em 1894 com a publicação de Leis psychologicas da evolução dos povos, Le Bon estabeleceu uma hierarquia entre os grupos sociais, estabelecendo a inferioridade de uns e a superioridade dos europeus (LE BON, 1910. p.8).
}

Revista Eletrônica da ANPHLAC, n. 13, p. 135-163, jul./dez. 2012. http://revista.anphlac.org.br/index.php/revista 
mesmo dentro dos estados oligárquicos vigentes. Esse foi o caso de La Raza Cósmica (1925) de José Vasconcelos, bem como o indigenismo oficial, promovido pela Secretaria de Educação Pública do México nos anos de 1920. Além disso, o nacionalismo culturalista de Leopoldo Lugones (1874-1938) e Ricardo Rojas (18821957) na Argentina do Centenário, também foi significativo, o que abriu espaço para o enaltecimento e a apropriação da "gauchesca", situando-a no próprio centro da literatura nacional (RAMOS, 2008, p.268).

Em Nuestra América, Martí também censurava os que propagavam a existência do ódio de raças, já que para ele as mesmas não existiam. Ele buscava combater proposições como a de Sarmiento, na obra Conflicto e Armonía de las Razas (1883), que imbuídas do positivismo defendiam a luta entre as raças. No entanto, Julio Ramos chama atenção para o fato de que Martí, ao fazer oposição ao determinismo racial que prevalecia no positivismo, acabou "encobrindo" as lutas e hierarquizações que efetivamente atuavam em termos étnicos na sociedade cubana.

O escritor cubano, de acordo com Ramos, tendeu a "hipostasiar" o conceito de uma América "mestiça" ou criolla, supostamente integrada. Assim, para Ramos (2008, p.344) se por um lado o desejo de unidade e integração étnica de Martí alude a uma condenação do racismo positivista, por outro encobre o elemento étnico como uma das medidas efetivas de exclusão nos projetos políticos dos Estados modernizadores de fins do século.

Gary Gerstle considera que o fato de Martí ter insistido na "isenção do conceito de raça”, estava relacionado ao medo de que uma ênfase excessiva na raça acabasse por revelar um aspecto da sociedade cubana que preferiam disfarçar: uma boa parte de sua população descendia de africanos. Portanto, os nacionalistas cubanos temiam que se Cuba expusesse "ao mundo sua face africana, ela seria categorizada, designada e menosprezada por ser uma nação negra”, a exemplo do Haiti (GERSTLE, 2008, p.432). Daí a necessidade de salientar a não existência de "raças".

O Ariel foi inspirado em uma perspectiva idealista, que se opunha ao positivismo de fins do século XIX (ARDAO, 1956). Mas Rodó, diferentemente de Martí, quando pensou a América e a necessidade de preservar a sua singularidade estava se referindo à tradição ibérica tão somente. O escritor uruguaio refletiu sobre os problemas do

Revista Eletrônica da ANPHLAC, n. 13, p. 135-163, jul./dez. 2012.

http://revista.anphlac.org.br/index.php/revista 
continente chegando mesmo a propor soluções concretas, como o aperfeiçoamento da democracia, o olhar para dentro, e o desenvolvimento da educação. Todavia, refletiu principalmente sobre a decadência espiritual e moral que poderia sobrevir com o rompimento da festejada tradição latina e ibérica.

Rodó era proveniente de uma oligarquia decadente, vivia em um país em que as questões raciais nunca estiveram em primeiro plano, já que o enorme afluxo de imigrantes desde os últimos trinta anos do século XIX contribuía para que a população branca predominasse. É possível conjeturarmos que as preocupações de Rodó - mesmo que seu discurso falasse de uma forma mais abrangente em nome da América estavam, de certa forma, voltadas mais especificamente para a região rioplatense.

Naquela época a população mestiça não podia ser ignorada, até porque a maioria das proposições a esse respeito atribuía o atraso do continente à mistura dos povos, o que teria ocasionado uma América "enferma”. Portanto, pensar a América, naquele momento, significava indubitavelmente pensar também a sua população. Já que Rodó defendia a singularidade latino-americana, e essa não deveria compreender culturas associadas ao atraso e à barbárie, a tradição ibérica poderia representar a especificidade da América que deveria ser valorizada.

Não encontramos no Ariel nenhuma menção à variedade dos povos que compunham o continente. É possível conjeturar que, guardadas as devidas proporções, as ideias raciais, que no século XIX e início do XX ocuparam o cenário político e intelectual tanto europeu quanto americano, influenciaram os escritos de Rodó. ${ }^{15}$ Embora o escritor uruguaio não tenha condenado a conformação dos povos da América, nos tempos da colônia, ele omitiu a contribuição indígena e negra no continente, dando ênfase à herança europeia, nomeadamente à latina e ibérica.

\footnotetext{
${ }^{15}$ Cabe ressaltar que posteriormente Rodó expressará algumas mudanças em suas considerações, isso pode ser observado no ensaio "Montalvo", na obra El Mirador de Próspero publicada em 1913. Antes mesmo disso, em 1909, ao escrever uma carta ao escritor boliviano Alcides Arguedas, em ocasião da publicação da primeira edição de Pueblo Enfermo, Rodó elucidava que os males que Arguedas atribuía à Bolívia, não seriam exclusivos do país andino, contudo, afetariam toda a América Hispânica. Não obstante, afirmava que estes males, apontados pelo boliviano, deveriam ser percebidos como transitórios. Nesse sentido, Rodó propunha, no lugar de "Pueblo Enfermo", "Pueblo Niño" uma vez que, para o escritor uruguaio "es concepto más amplio y justo quizás, y no excluye, sino que, en cierto modo, incluye al otro; porque la primera infancia tiene enfermedades propias y peculiares, cuyo más eficaz remedio radica en la propia fuerza de la vida, nueva y pujante, para saltar sobre los obstáculos que se le oponen" (RODÓ. Apud. ARGUEDAS, 1937, p.9).
}

Revista Eletrônica da ANPHLAC, n. 13, p. 135-163, jul./dez. 2012.

http://revista.anphlac.org.br/index.php/revista 
Rodó era profundo admirador de escritores como Ernest Rénan e foi influenciado por suas ideias. Todavia, isso não o impediu de em determinados momentos revelar uma postura crítica em relação a algumas ideias desse filósofo francês, como por exemplo, no que tange à questão da democracia. ${ }^{16}$

De todo modo, se havia em Rodó e Martí uma crítica contundente ao positivismo de fins do século XIX, que se expressava principalmente na oposição de importar soluções definitivas para questões latino-americanas, os caminhos que cada um percorreu para definir a identidade latino-americana foram desiguais, já que o escritor cubano incluiu os indígenas e os negros nessa identidade e o escritor uruguaio valorizou nela apenas a tradição ibérica. No entanto, concordavam ambos, que uma regeneração deveria ocorrer, e que a juventude seria a responsável por levar adiante tal transformação. Para isso, a arena política precisaria ser ocupada, para Martí em conjunto com os "naturais da terra", já na concepção de Rodó principalmente pela aristocracia do espírito.

Dessa forma, Martí e Rodó, compartilharam certos valores comuns no final do século e produziram enunciações semelhantes em relação à América. Defenderam a importância da educação para o desenvolvimento da América Latina e se preocuparam com a valorização do que era característico dos povos americanos. Além disso, e na contramão do que era considerado na época, ${ }^{17}$ negaram o atraso do continente como algo que lhe era inerente. Ambos os autores perceberam tal atraso (não obstante Martí tenha deixado isso mais evidente) como estando ligado ao passado, à exploração colonial, e à manutenção de práticas coloniais mesmo após a independência, e também ambos direcionaram seus discursos/textos à juventude do continente.

De acordo com Claudia Wasserman (2004, p.142), os dois autores operaram com uma concepção de história "linear, descritiva e causal", na qual o passado e presente apareciam concatenados. Dessa maneira, o passado agiria de forma a explicar a procedência dos males, os erros de conduta, e até os desvios de direção. O presente, por

\footnotetext{
${ }^{16}$ Para Rénan a concepção de vida numa sociedade cujo espírito democrático predominasse resultaria em uma busca exclusivamente pelo bem-estar material, destruindo a possibilidade de uma vida voltada para os interesses ideais. Rodó discordava de Rénan neste ponto, pois considerava que a partir do momento em que houvesse oportunidades iguais na educação, uma aristocracia natural - dos melhores - surgiria e poderia, mediante um ideal desinteressado, conduzir a sociedade.

${ }^{17}$ Sob a influência das teorias cientificistas europeias do século XVIII e XIX.
}

Revista Eletrônica da ANPHLAC, n. 13, p. 135-163, jul./dez. 2012.

http://revista.anphlac.org.br/index.php/revista 
sua vez, embora visto como incerto, já que era oriundo de tal passado, representava o momento adequado para se melhorar, de modo a reverter os males e os problemas vigentes. Portanto, apresentava-se como conjunto de alternativas, para o bem ou para o mal, dependendo de como fosse conduzido. Foi precisamente para a ação nesse presente que a juventude fora mobilizada, tanto por Martí como por Rodó. Tornados destino dos seus discursos, os jovens são os protagonistas da transformação buscada.

Assim sendo, os discursos de Martí e o ensaio de Rodó obtiveram um êxito imediato. Tanto um como o outro podem ser vistos como intelectuais que definiram uma identidade latino-americana e que atuaram como divisores de águas no modo como a América Latina passou a ser pensada. Influenciaram profundamente seus coetâneos e a geração que os sucedeu, e também foram capazes de estimular uma mudança de comportamento em relação à "Nuestra América". Talvez aí esteja uma das grandes contribuições destes autores, trazer, em um momento de conjeturas pessimistas a respeito do futuro latino-americano, esperanças aliadas a indicações de novos caminhos que poderiam levar à inversão da situação que enfrentavam. Para Martí e Rodó, o trabalho era árduo, e o caminho longo, mas a América estava preparada - ou ao menos preparando-se - para segui-lo e alcançar, assim, um futuro promissor.

\section{Referências Bibliográficas}

ARDAO, Arturo. La filosofía en el Uruguay en el siglo XX., México; Buenos Aires: Fondo de Cultura Económica, 1956.

ARGUEDAS, Alcides. Pueblo enfermo. Chile: Ediciones Ercilla, 1937.

BARRACLOUGH, Geofrey. Introdução à história contemporânea. Rio de Janeiro: Zahar, 1964.

GERSTLE, Gary. Raça e nação nos Estados Unidos, México e Cuba, 1880-1940. In: PAMPLONA, Marco Antonio V. e DOYLE, D. H. (Orgs.). Nacionalismo no Novo Mundo: a formação de Estados-nação no século XIX. Rio de Janeiro: Editora Record, 2008. p.409-450.

GOLDMAN, Noemi; SALVATORE, Ricardo (Org.). Caudilhismos Rioplatenses: nuevas miradas a un viejo problema. Buenos Aires: Eudeba, 2005.

Revista Eletrônica da ANPHLAC, n. 13, p. 135-163, jul./dez. 2012.

http://revista.anphlac.org.br/index.php/revista 
JOZEF, Bella. História da literatura hispano-americana. Rio de Janeiro: Editora da UFRJ, 2005.

KRAUSE, Enrique. Os redentores: ideias e poder na América Latina. São Paulo: Saraiva, 2011.

MARTÍ, José. Obras completas. Habana: Editorial Nacional de Cuba, 1963.

. Textos de combate. México: Universidad Autónoma de México, 1980.

MITRE, Antonio. Estado, nação e território na Bolívia oligárquica, 1850-1914. In:

PAMPLONA, Marco A.; MÄDER, Maria Elisa (Orgs.). Revoluções de independências e nacionalismos nas Américas: Peru e Bolívia. São Paulo: Paz e Terra, 2010. p.193-237.

OLIVEIRA, Lúcia Lippi. Diálogos intermitentes: relações entre Brasil e América Latina. In: Sociologias, Porto Alegre, ano 7, nº14, p.110-129, jul/dez de 2005.

PAMPLONA, Marco Antonio V. e DOYLE, Don H. (Orgs.). Nacionalismo no Novo Mundo: a formação de Estados-Nação no século XIX. Rio de Janeiro: Record, 2008.

RAMA, Angel. A cidade das letras. São Paulo: Editora Brasiliense, 1984.

La crítica de la cultura en América Latina. Caracas: Biblioteca Ayacucho, 1985.

RAMOS, Julio. Desencontros da modernidade na América Latina: literatura. Belo Horizonte e política no século 19: Editora UFMG, 2008.

RODÓ, José Enrique. Ariel. Tradução: Denise Bottmann. Campinas: Editora da UNICAMP, 1991.

ROTKER, Susana. Fundación de una escritura: las crónicas de José Martí. Habana: Casa de las Américas, 1992.

SANTOS, Fábio Muruci dos. Os homens já se entendem em Babel: mito e história da América em Oliveira Lima, José Enrique Rodó e José Martí. Rio de Janeiro, 2004. Tese (Doutorado em História) - UFRJ/IFCS.

STEPAN, Nancy. "A hora da eugenia” raça, gênero e nação na América Latina. Rio de Janeiro: Editora Fiocruz, 2005.

TELLES, Gilberto Mendonça. Vanguarda europeia e modernismo brasileiro: apresentação e crítica dos principais manifestos vanguardistas. 12a ed. Petrópolis: Vozes, 1992.

Revista Eletrônica da ANPHLAC, n. 13, p. 135-163, jul./dez. 2012.

http://revista.anphlac.org.br/index.php/revista 
WASSERMAN, Claudia. Recursos intelectuais latino-americanos: "Nuestra América" de José Martí e "Ariel” de José Enrique Rodó - as condições de produção e o processo de repercussão do pensamento identitário. In: PRADO, Maria Emília (Org.). Colóquio tradição e modernidade no mundo ibero-americano. Rio de Janeiro: Instituto Histórico Geográfico Brasileiro/CNPq, 2004. v.1. p.135-144.

ZANETTI, Susana. Modernidad y religación: una perspectiva continental (1880-1916). In: PIZARRO, Ana (Org.). América Latina: palabra, literatura e cultura. Vol.2 Emancipação do discurso. São Paulo: Fundação Memorial da América Latina, 1994.

Revista Eletrônica da ANPHLAC, n. 13, p. 135-163, jul./dez. 2012.

http://revista.anphlac.org.br/index.php/revista 